\title{
Baseflow concentrations of nitrogen and phosphorus in forested
}

\section{2 headwaters in Japan}

4 Zhao Zhang ${ }^{1,2 *}$, Takehiko Fukushima ${ }^{2}$, Peijun $\mathrm{Shi}^{1}$, Fulu $\mathrm{Tao}^{2}$, Yuichi Onda ${ }^{2}$, Takashi Gomi ${ }^{3}$, Shigeru Mizugaki ${ }^{2}$, Yuko Asano ${ }^{6}$, Ken'ichirou Kosugi $^{4}$ Shinya Hiramatsu ${ }^{5}$, Hikaru Kitahara ${ }^{5}$,

6 Koichiro Kuraji $^{6}$, Tomomi Terajima ${ }^{7}$, Kazuo Matsushige ${ }^{8}$

8 ' ${ }^{1}$ State Key Laboratory of Earth Surface Processes and Resource Ecology, Beiing Normal University, Beijing 100875, China

$10{ }^{2}$ Graduate School of Life and Environmental Science, University of Tsukuba, Tsukuba 305-8572, Japan

${ }^{3}$ Disaster Prevention Research Institute, Kyoto University, Kyoto 611-0011, Japan

$12{ }^{4}$ Graduate School of Agriculture, Kyoto University, Kyoto 606-8502, Japan

${ }^{5}$ Faculty of Agriculture, Shinshu University, Nagano 399-4598, Japan

$14{ }^{6}$ Graduate School of Agricultural and Life Science, University of Tokyo, Tokyo 489-0031, Japan

${ }^{7}$ Faculty of Science, Chiba University, Chiba 263-8522, Japan

$16{ }^{8}$ National Institute for Environmental Studies, Tsukuba 886-0387, Japan

*Corresponding Author: Zhao Zhang, State Key Laboratory of Earth Surface Processes and

20 Resource Ecology, Beiing Normal University, No. 19 Street of Xinjiekouwai, Beijing 100875,

China, Tel \& Fax: +86-10-5880-2158

22 Email: zhzhao22@yahoo.com 


\section{Abstract}

2 A comprehensive investigation on all dissolved nitrogen and phosphorus components at both local and regional scales in the headwaters from forested watersheds is valuable to improve

4 our understanding of the factors controlling water quality. Here, we investigated the baseflow concentrations of dissolved nitrogen and phosphorus components, N:P ratio, and their

6 associations with region and vegetation type in forested headwaters in fives regions of Japan. We found that inorganic nitrogen and phosphorus were the dominant components in the 26

8 temperate forested streams, rather than organic forms. There were significant positive correlations between the concentrations of $\mathrm{N}$ and $\mathrm{P}$ components. Furthermore, the regional

10 patterns of the concentrations of nitrate, dissolved inorganic P (DIP), and dissolved total $\mathrm{N}$ (DTN) and P (DTP) were similar. Our results suggest that the regional patterns of the concentrations of $\mathrm{N}$ and $\mathrm{P}$ components should be related to the regional atmospheric deposition of both $\mathrm{N}$ and P nutrients. We also found that the nitrate and DTN concentrations

14 were higher in man-made evergreen conifer (EC) than those in the natural deciduous broadleaf (DB). In contrast, the DIP and DTP concentrations in EC were lower than those in

16 DB. The uniformly higher $\mathrm{N}: \mathrm{P}$ ratio in $\mathrm{EC}$ - than in $\mathrm{DB}$-forested streams for each region suggest that EC-forested streams could be more affected by P-limited than DB-forested streams when $\mathrm{N}$ inputs from atmospheric sources increased.

Keywords: Forested headwater; Nitrogen; Phosphorus; N:P ratio; Nutrient limitation; Vegetation 


\section{Introduction}

2 Scientific interests in determining the relationship between water quality and its environmental controls are increasing due to the increasing human influences on water

4 quality. However there have been few studies on all the dissolved nutrients at both the local and regional scales in the headwaters of forested watersheds that are relatively free from the

6 human influences (Ahearn et al., 2004). Water chemistry in small forest watersheds is very sensitive to precipitation/discharge. It is difficult to compare the concentrations during

8 stormflow conditions among regions with different climates. An investigation of nutrient concentrations during baseflow conditions will improve our understanding of the factors

10 controlling water quality in forested watersheds.

Extensive studies on the "N-saturation" status have indicated a major role of atmospheric

12 deposition on nitrate concentrations in Japanese forested streams (e.g., Yoh, 2001; Shibata et al., 2001). In contrast, there are relatively few studies on the concentrations of $\mathrm{P}$ components.

14 Previous studies did indicate that certain factors, including atmospheric deposition (Kunimatsu et al., 2001; Komai, 2004), vegetation (Fukushima and Matsushige, 1995),

16 geology (Wakamatsu et al., 2006), and watershed management (Takeda, 2002), had an influence on the concentrations of P components in forested watersheds. Spatial differences

18 in atmospheric deposition have generally contributed to the regional distribution of nitrate concentration in forested streams. However, due to large variations in annual deposition and a

20 lack of long-term data at the regional scale, the relationship between concentrations of dissolved P components and atmospheric deposition has seldom been investigated (Komai,

22 2004; Tsukuda et al., 2004). The contribution of atmospheric P deposition in forested ecosystems was indicated by comparing nutrient budgets in three watersheds on the same

24 bedrock by Kunimatsu et al. (2001). Fukushima and Matsushige (1995) found a positive relationship between the concentrations of $\mathrm{P}$ components and mean forest age. More recently, 
a nationwide survey in forested streams (Wakamatsu et al., 2006) has showed a distinct

2 regional pattern in DIP concentrations and its association with bedrock types. Watersheds on sedimentary rocks (Paleozoic sedimentary rocks in particular) had higher DIP concentration

4 than those on igneous or metamorphic rocks (Wakamatsu et al., 2006). Motoshita et al. (2003) found a high correlation between DTP and dissolved organic matter (DOM), which suggests

6 that DOM has a significant influence on P leaching. All these studies described only one specific factor controlling P concentration, although some of them also suggested that other

8 factors should have potential influences. Further investigations are necessary to identify the primary factors that control the concentrations of $\mathrm{P}$ components in the forested streams

10 draining the catchments, particularly by considering the concentrations of $\mathrm{P}$ components at both local and regional scales.

12 Furthermore, the forested headwater watersheds, where there is no direct application of fertilizers, are commonly considered to be infertile (Aerts, 1996; Bobbink et al., 1998).

14 However, in many cases, it is unclear whether it is $\mathrm{N}$ or $\mathrm{P}$ that limits biological productivity. $\mathrm{P}$ is commonly believed as the limiting nutrient in the freshwater, whereas $\mathrm{N}$ a limiting factor 16 in estuarine or marine waters (e.g., Vitousek and Howarth, 1991; Turner et al., 2003). However, many researchers have suggested that $\mathrm{N}$ alone, or $\mathrm{N}$ and $\mathrm{P}$ together may limit 18 biological productivity in nutrient-poor forested ecosystems (Elser et al., 1990; Interlandi and Kilham, 1998; Edwards et al., 2000; Turner et al. 2003). The N:P ratio has gained worldwide acceptance as an indicator of the regulation of organism growth and nutrient cycling and has successfully been used in several studies of aquatic areas (Sakamoto, 1966; Edwards et al., 2000; Turner et al., 2003). Therefore, the N:P ratio in forested streams is fundamental and important to assess the potential biological impacts of both $\mathrm{N}$ and $\mathrm{P}$ concentrations, and to 24 identify the appropriate management strategies to reduce nutrient loss at the watershed scale. 
In this study, we sampled headwaters during baseflow condition throughout a full year in

2 forested areas of five regions with different climatic and geological environments to investigate the influences of forests on the nutrient concentrations and their limitations. The

4 aims of this study are 1) to characterize the baseflow concentrations of dissolved $\mathrm{N}$ and $\mathrm{P}$ components, and further to determine the N:P ratio; 2) to investigate the possible controlling

6 factors underlying the concentration patterns of $\mathrm{N}$ and P. Finally, we discuss the potential limitation of available nutrients in downstream water bodies.

\section{Methods}

$10 \quad$ 2.1. Site descriptions

We chose a set of headwater streams in the watersheds (Fig.1) across five regions (Aichi,

12 Kochi, Mie, Nagano, and Tokyo) according to the following criteria: (1) under different climatic, geological, and topographic conditions; (2) first or second-order streams; (3)

14 watersheds entirely forested; and (4) lack of obvious lakes or wetlands in the watershed, based on topographic maps. All of the streams are fast flowing and the streambeds are 16 composed of boulders and large cobbles with little accumulation of fine sediment. In each region we selected four to seven streams with similar geological environments, where the main vegetation, including evergreen conifer (EC) plantation, natural deciduous broadleaf (DB), and mixing forests of both $\mathrm{EC}$ and $\mathrm{DB}$, is representative of the region. The general information for the five regions and the watersheds, including the watershed areas, proportions of EC and DB, etc. is presented in Table 1. The sites characteristic is briefly 22 summarized below, and more information is available from Zhang (2007).

The Aichi sites are located in the Aichi Research Forest of the University of Tokyo, east of

24 Inuyama in Aichi Prefecture. The watershed is composed mainly of Neogene sediments with undulating topography. The Kochi sites are located in the Tsuzuragawa watershed, which is 
part of the east tributary of the Shimanto River, southeast of Taishouchou in Kochi Prefecture.

2 The terrain comprises somewhat steep and incised hillsides. Sandstone and pelitic rocks are dominant in these areas. The Mie sites are located in Taikichou, Mie Prefecture, and are

4 characterised by generally steep slopes. The prevalent rock is gneiss, with typical brown forest soil cover. The Nagano sites are located in the Terasawayama Education and Research

6 Forest of Shinshu University in Ina, Nagano Prefecture. The Tanazawagawa, a small tributary of the Tenryu River, discharges from this area. As in Mie, steep slopes are a common feature

8 of this area. The watersheds are underlain by granite. The Tokyo sites are located in the Joubanzawa watershed, a tributary of the Arakawa River, and near the headwaters of the

10 Narikigawa in Tokyo. Steep, incised hillsides are common in this area. The watershed is underlain by sandstone, pelitic rocks, and chert.

\subsection{Collection and analysis of water samples}

14 The sampling and analyzing methodology used in this study was described by Zhang et al. (2007a). While some streams have been added to or dropped from the survey over time, we

16 present here the data from a set of 26 streams that were sampled from June 2004 to May 2005 under baseflow conditions. Samples were not taken immediately after rain events, to avoid stormflow conditions. In order to guarantee water sampling free from rainfall influence, we further rechecked the rainfall records at each station. Some samples were excluded when only

20 a little rainfall occurred during the sampling days (although the water levels did not change much), or when strong rainfall $\left(>80 \mathrm{~mm} \mathrm{day}^{-1}\right)$ occurred less than 5 days before the sampling

22 day. The sampling days used in this study are shown for Aichi and Mie as examples in Fig. 2. Samples were collected in $500 \mathrm{ml}$ clean polyethylene bottles that were rinsed with the stream 24 water before sampling. All samples were filtered $(0.45 \mu \mathrm{m}$ Whatman GF/F, Chicago, USA) soon after they were shipped by refrigerated express to our laboratory, and stored at $1{ }^{\circ} \mathrm{C}$ for 
further analysis. A series of analyses were carried out on the filtered subsamples. Using an

2 Auto-analyzer (Traacs 800, Bran Luebbe Co., New York, U.S.A.), we measured nutrients including $\mathrm{NH}_{4}-\mathrm{N}, \mathrm{NO}_{2}-\mathrm{N}, \mathrm{NO}_{3}+\mathrm{NO}_{2}-\mathrm{N}$, DIP (molybdate-reactive fraction of $\mathrm{P}$ ), total

4 dissolved nitrogen (DTN: persulfate oxidation method), and total dissolved phosphorus (DTP: persulfate oxidation method). Dissolved organic nitrogen (DON) and dissolved organic

6 phosphorus (DOP) were determined as the difference between DTN and inorganic $\mathrm{N}\left(\mathrm{NH}_{4}-\mathrm{N}\right.$ $+\mathrm{NO}_{2}-\mathrm{N}+\mathrm{NO}_{3}-\mathrm{N}$ ) and between DTP and DIP, respectively. The limits of detection (LOD)

8 were approximately $0.367 \mu \mathrm{mol} 1^{-1}$ for $\mathrm{N}$, and $0.032 \mu \mathrm{mol} 1^{-1}$ for $\mathrm{P}$. The N:P ratio was calculated from the molar ratio of dissolved total nitrogen (DTN) and DTP, rather than 10 inorganic forms. It is generally accepted that the limiting nutrients for autotrophs and heterotrophs are inorganic and organic nutrients, respectively. However, the biomes have

12 shown astonishing adaptability (e.g., for nutrient storage, and adaptations allowing access to various sources of nutrients in the ambient environment). For example, the dominant

14 phototroph Rivularia displays high phosphatase activity, making it well suited for survival in a low-P environment (Whitton et al., 1998). In addition, plants have the ability to take up 16 dissolved organic nitrogen (Lipson and Näsholm, 2001).

\subsection{Data processing and treatment}

18 To minimize statistical bias, we recorded concentrations below our limit of detection (LOD) as a fraction of the limit, rather than as zero (Newman et al., 1989). Since more than $65 \%$ of the measured values of $\mathrm{NH}_{4}-\mathrm{N}$ and $\mathrm{NO}_{2}-\mathrm{N}$ were below the LOD, these values were coded in the data set as one-fourth of the LOD. Because of the analytical uncertainty, we did not interpret the data of $\mathrm{NH}_{4}-\mathrm{N}$ and $\mathrm{NO}_{2}-\mathrm{N}$ further in this study. Other components were coded as one half of the LOD. Descriptive statistics were first conducted to investigate the level of water quality for the complete data set. Then we investigated the correlation between the 
water quality items. The variance among the repeated measurements should be negligible in comparison with that among regions. We grouped the data by region, and performed a oneway analysis of variance (ANOVA) to examine the regional distribution of $\mathrm{N}$ and $\mathrm{P}$ constituents and N:P ratio. The Tukey multiple comparison and F-test were used to identify the significant difference. We also conducted the ANOVA analyses to investigate the

6 differences between two vegetation types, including EC and DB forests, in influencing the concentrations of $\mathrm{N}$ and $\mathrm{P}$ constituents, and the $\mathrm{N}: \mathrm{P}$ ratio. We conducted ANCOVA (analysis

8 of covariance) to assess the relative impacts of region-specific factors (RSF) and vegetation type on water quality. To do so, we analyzed the dependency of water quality on the two 10 factors, then ranked their respective weights ( $F$ values). In this paper, RSF is defined as a comprehensive environmental factor (including specific climatic, geological, and topographic features), which describes environmental impacts on a regional scale.

The experimental design did not allow us to investigate in detail the chemical properties of 14 the soil and related bio-geochemical processes in the forest ecosystems. We therefore implicitly made two assumptions:

1) Although forest ecosystems exist at the interface between four spheres, the atmosphere, biosphere, hydrosphere, and geosphere, which are dynamic and interactive, we assumed that the site characteristics (e.g., soil properties, vegetation cover) are not usually subject to significant changes on a time scale of months or years, so that the current characteristics are long-term consequences of the interactions between the four spheres. Thus, the baseflow concentrations of water quality items in these forested streams are the important indicators of the watershed.

2) If sites are located in the same region (therefore generally under similar climatic and geological conditions) but have different forests (EC and DB), then both forest covers determine their own specific landscapes and soil properties which are long-term 
consequences of vegetation phenology, adaptation, and interactions within the forest ecosystem. Numerous publications have indicated the significant differences, including soil properties, litter deposition rate and seasonality of vegetation cover, between these two contrasting forests (e.g. Vitousek, 1982; Kavvadias et al., 2001; Liu et al., 2004; Richardson et al., 2004).

6

\section{Results}

\subsection{Characteristics of nutrient concentrations and $N: P$ ratio under baseflow conditions}

The concentrations of DON, DIN, DTN, DOP, DIP, and DTP in the 26 streams across the

10 five regions in our study are presented in Table 2. N:P ratio ranged from 7.04 to 1858 . The maximum concentrations of DOP, DIP, and DTP were about 21, 52, and 41 times higher than

12 their respective minimum values. In contrast, the maximum concentrations of $\mathrm{NO}_{3}-\mathrm{N}, \mathrm{DIN}$, and DTN were about 218, 176, and 148 times higher than their respective minimum values..

14 The inorganic $\mathrm{N}$ and $\mathrm{P}$ were the dominant components, constituting of $74 \% \pm 21$ dissolved $\mathrm{N}$, and $59 \% \pm 8 \%$ of dissolved $\mathrm{P}$, respectively. Among the inorganic nitrogen components, $\mathrm{NO}_{3}$ -

$16 \mathrm{~N}$ was the dominant component, accounting from $66 \%$ to $100 \%$. In comparison with previous reports, the concentrations of nitrate in our study are within the typical ranges (e.g. Yoh et al.,

18 2001; Shibata et al., 2001). According to the large-scale survey of DIP concentration in Japanese forested streams (Wakamatsu et al., 2006), 67.9\% of our sites (Table 3) could be

20 classified as low $\mathrm{P}\left(<0.13 \mu \mathrm{mol} \mathrm{l}^{-1}\right), 11.7 \%$ could be medium $\mathrm{P}\left(0.13-0.32 \mu \mathrm{mol} 1^{-1}\right)$, and $21.4 \%$ could be high $\mathrm{P}\left(>0.32 \mu \mathrm{mol} 1^{-1}\right)$.

22 Generally, there were significantly positive correlations between all the nutrient forms except the correlation between dissolve organic N (DON) and DIP $(r=0.042, p=0.541)$

24 (Table 4). In contrast, the correlations between dissolved organic C (DOC) and all nutrient 
forms were insignificant (except the correlation between DOC and DON; $r=0.159, p=$

2 0.018), and generally negative (except the correlations between DOC and two organic nutrient forms, DON and DOP).

\section{3.2. Regional characteristics of nutrient concentrations and $N: P$ ratio}

Using the ANOVA method, we compared the mean concentrations of $\mathrm{N}$ and $\mathrm{P}$ components

6 and N:P ratio according to sampling regions (Table 3). Our results showed that the concentrations of $\mathrm{NO}_{3}-\mathrm{N}$ and DTN in Tokyo and Nagano were significantly higher than those

8 in the other three regions $(p<0.01)$. There is no significant difference among the five regions in terms of the concentration of DON. The regional patterns of DIP and DTP concentrations

10 are the same as the pattern of nitrate concentration. DIP and DTP concentrations in Aichi were significantly lower $(\mathrm{p}<0.01)$ than those in Nagano and Tokyo. DOP concentration and

$12 \mathrm{~N}: \mathrm{P}$ were higher in Tokyo and Nagano. The higher nitrate concentrations of in Tokyo and Nagano agreed well with the previous studies (Toda et al., 2000; Yoh et al., 2001).

\subsection{The effects of vegetation type on water quality items and $\mathrm{N}: \mathrm{P}$ ratio}

16 Using the ANOVA method, we also compared the concentrations of DIP, DTP, $\mathrm{NO}_{3}-\mathrm{N}, \mathrm{DTN}$, DOC, and N:P ratio in the DB- and EC- forested streams in each region (Fig.3). We found 18 that the concentrations of DIP (Fig.3a), DTP (Fig.3b), and DOC (Fig.3e) were generally higher in DB-forested streams than those in EC-forested streams, especially for the DIP concentration in Nagano $(p<0.001)$, DTP concentration in Kochi $(p<0.05)$, and DOC concentration in Nagano $(p<0.001)$. In contrast, in all DB-forested streams, the concentrations of $\mathrm{NO}_{3}-\mathrm{N}$ (Fig.3c), DTN (Fig.3d), and N:P ratio (Fig.3f) were lower than those of EC-forested streams, especially in Nagano ( $p<0.001)$, Aichi $(p<0.01)$, Kochi $(p<$ 0.05), and Tokyo $(p<0.05)$. In comparison with the concentrations of $\mathrm{N}$ and $\mathrm{P}$ components, 
and $\mathrm{N}: \mathrm{P}$ ratio, there was less variability in DOC concentrations across the regions, and also

2 between the two vegetation types, except the case in Nagano.

To compare the relative impacts of the two main factors, i.e. RSF and vegetation (DB, EC,

4 and mixing forest), using ANCOVA we calculated the weights of RSF and vegetation with respect to the nutrient concentrations and N:P ratio using the whole dataset from the five

6 regions. For RSF, the $F$ values of $\mathrm{NO}_{3}-\mathrm{N}, \mathrm{DTN}, \mathrm{DIP}, \mathrm{DTP}$, and $\mathrm{N}: \mathrm{P}$ were $60.93(\mathrm{p}<0.001)$, $57.41(\mathrm{p}<0.001), 33.76(\mathrm{p}<0.001), 32.88(\mathrm{p}<0.001)$, and $8.98(\mathrm{p}<0.001)$, respectively.

8 The corresponding values for vegetation were $16.79(\mathrm{p}<0.001), 15.13(\mathrm{p}<0.001), 8.12(\mathrm{p}<$ 0.05), $7.77(\mathrm{p}<0.001)$, and $5.86(\mathrm{p}<0.001)$, respectively. All $F$ values for RSF were higher

10 than those for vegetation, suggesting that RSF plays a more important role in controlling the nutrient concentrations and $\mathrm{N}: \mathrm{P}$ ratio.

\subsection{Potential limiting nutrients in stream water during baseflow conditions}

14 To quantitatively describe the limiting nutrients, we assumed that phototrophs are likely to be limited by $\mathrm{N}$ when the ambient $\mathrm{N}: \mathrm{P}$ ratio is less than 20 , and limited by $\mathrm{P}$ when the $\mathrm{N}: \mathrm{P}$

16 ratio is greater than 34 (Sakamoto 1966; Turner et al. 2003). The plots of DTP and DTN concentrations by vegetation type for each region are shown in Figure 4. We found almost all

$18 \mathrm{~N}: \mathrm{P}$ ratios were greater than 34, except DB-forested areas in Nagano, where they were less than 20. These results suggest that the forested streams should be generally P-limited during baseflow conditions, except the DB-forested streams in Nagano. The N:P ratios of ECforested streams at Aichi, Kochi and Tokyo were above the P-limited line, and quite higher than those for DB-forested streams. So the EC-forested streams could be more affected by Plimited than DB-forested streams when $\mathrm{N}$ inputs from atmospheric sources increased. 


\section{Discussion}

2 4.1. Factors controlling nutreint concentrations and $N: P$ ratio during baseflow condition in forested streams

4 Since the regional distribution of $\mathrm{NO}_{3}-\mathrm{N}$ concentration in Japanese forested streams was attributed to region-specific atmospheric deposition (e.g., Yoh et at., 2001; Shibata et al.,

6 2001), we ascribe the higher nitrate concentrations in Nagano and Tokyo to the higher $\mathrm{N}$ deposition rate. As for the regional distribution of DIP concentration, a nationwide survey has

8 indicated that watersheds on sedimentary rocks had higher DIP concentration (especially Paleozoic compared to Mesozoic and Cenozoic sedimentary rocks) than those on igneous or

10 metamorphic rocks (Wakamatsu et al., 2006). However, in our study, the lowest DIP concentration was found in Aichi watersheds, which are on sedimentary upper Paleozoic

12 sandstone (Zhang, 2007). The highest DIP concentration was found in Tokyo, where the watershed is underlain by pelitic, sandstone, and chert. Therefore, the relationship between

14 geology and DIP concentration could become complicated when more environment factors were taken into account.

16 The regional patterns of DIP and DTP concentrations across the five regions were consistent with the pattern of $\mathrm{NO}_{3}-\mathrm{N}$ (the main constituent of $\mathrm{N}$ ) concentration. This could be related to the regional patterns of atmospheric $\mathrm{N}$ and $\mathrm{P}$ deposition. Extensive surveys of baseflow $\mathrm{NO}_{3}$ N concentration in Japan forested streams (Shibata et al. 2001; Yoh et al. 2001) have showed that region-specific characteristic of atmospheric $\mathrm{N}$ deposition. However there has never such investigation on $\mathrm{P}$ deposition in Japan. The good correlations between $\mathrm{N}$ and $\mathrm{P}$ deposition in the four forested watersheds (Fig.5) suggest that spatial distributions of atmospheric $\mathrm{N}$ and $\mathrm{P}$ deposition should be similar. It seems that the similar regional patterns of DIP, DTP, $\mathrm{NO}_{3}-\mathrm{N}$, and DTN across the five regions are due to the similar spatial patterns of $\mathrm{N}$ and $\mathrm{P}$ deposition in Japan forests. However, Tsukuda et al. (2006) suggested that atmospheric P deposition 
should be similar throughout the Japan archipelago. Comprehensive investigations on the inputs and outputs of $\mathrm{N}$, and particularly, P from forested watersheds are necessary.

\subsection{The role of vegetation in controlling of $\mathrm{N}: \mathrm{P}$ ratio}

4 Because natural plant canopies can affect deposition rates by changing the physical environment and surface area available for nutrient deposition (Redfield, 1998; Shibata,

6 2004), higher dissolved $P$ concentrations in stream water could be found in the watersheds covered by EC than those covered by DB, as the case for nitrate concentration (Zhang, 2007).

8 However, in the present study, we found the association of DTP and DIP concentrations with vegetation types (Figs.3a, 3b) was the inverse of that for $\mathrm{NO}_{3}-\mathrm{N}$ and DTN concentrations

10 (Figs. 3c, 3d). Consequently, a higher N:P ratio was observed in EC than that in DB (Fig. 1f). We found the EC and DB had similar influences on the concentrations of DOC and P

12 components (Figs.3a, 3b, 3e). In a series of soil column experiments, Motoshita et al. (2003) found that leaching of DTP from soil was strongly associated with leaching of DOM; and P

14 was adsorbed by or formed complexes with DOM, which suggested that DOM-facilitated transport was likely to be a dominant process controlling P leaching from soil. However, we

16 cannot ascribe the higher concentrations of dissolved $\mathrm{P}$ components in DB forests only to DOM-facilitated P leaching from soil, because we found no significant correlations between

18 DOC and dissolved P constituents either across the five regions (Table 4) or in each region (results not shown). The inconsistence may be due to the different approaches used. That is, 20 our study involved frequently changing environmental conditions and included more variables (Zhang 2007). Nevertheless, the similarity in the influence of vegetation types on

22 the concentrations of DOC, DTP, and DIP suggests that DOC could affect DTP and DIP concentrations to some extent. 
In comparison with EC-forested watersheds, DB-forested ecosystems exhibit a higher

2 decomposition rate of litter (Webster and Benfield, 1986; Richardson et al., 2004), more distinct seasonality (e.g. Liu et al., 2004), and significantly higher litterfall (Kavvadias et al.,

4 2001; Liu et al., 2001), which result in rapid turnover of organic matter, nutrients, and energy from the vegetation to the soils (Vitousek 1982; Liu et al. 2004), consequently different

6 riparian and/or in-stream processes. Such characteristic reinforces the potential for higher DOM in DB- than EC-forested watersheds.

8 We found the N:P ratio in EC-forested streams was higher than that in DB-forested streams. Although the reasons need to be further investigated, the finding has far-reaching

10 significance for forest ecosystems. The N:P ratio is not only useful to evaluate the limiting nutrient for downstream water bodies, but also a parameter to assess the functioning of

12 terrestrial ecosystems. Increases of the N:P ratios in litter are commonly associated with reductions in litter decomposition rates, release of $\mathrm{P}$ from litter, and biomass and activity of 14 decomposer microbes (Wardle et al., 2004). All these ecosystem properties are strongly related to the decline phase of forested ecosystems in tropical, temperate, and boreal zones

16 (Wardle et al., 2004).

\section{5. Conclusions}

In this study, we investigated the baseflow concentrations of dissolved $\mathrm{N}$ and $\mathrm{P}, \mathrm{N}: \mathrm{P}$ ratio, 20 and their associations with region and vegetation in forested headwaters of five regions (Aichi, Kochi, Mie, Nagano, and Tokyo) in Japan. The concentration ranges of nitrate, DON,

22 DTN, DOP, DIP, and DTP in the baseflow were quite large across the five regions. Both the concentrations of all these nutrient components and N:P ratio have strong region-specific characteristics. There were significant positive correlations between the concentrations of $\mathrm{N}$ and $\mathrm{P}$ components. Also the regional patterns of the concentrations of nitrate, dissolved 
inorganic P (DIP), and dissolved total $\mathrm{N}$ (DTN) and P (DTP) were similar. Our results suggest the regional patterns of the concentrations of $\mathrm{N}$ and $\mathrm{P}$ components be related to the regional atmospheric deposition of both $\mathrm{N}$ and $\mathrm{P}$ nutrients.

4 Secondly to the influences of region, the concentrations of $\mathrm{N}$ and $\mathrm{P}$ components were also associated with the vegetation types.

6 According to the N:P ratio, the stream waters in the five regions were classified as $\mathrm{P}$ limitation under baseflow condition, except the streams in DB-forested Nagano.

8 Comprehensive investigations on the inputs and outputs of $\mathrm{N}$, and particularly, $\mathrm{P}$ components in forested watersheds will help to elucidate the associations between the

10 concentrations of $\mathrm{N}$ and $\mathrm{P}$ in stream waters, their regional patterns, as well as the limiting nutrients.

\section{Acknowledgements}

14 This study was funded by the Japan Science and Technology Agency, Core Research for Evolutional Science and Technology. We are grateful to three anonymous reviewers for their constructive comments. 


\section{References}

2 Aerts R. Nutrient resorption from senescing leaves of perennials: are there general patterns? J Ecol 1996; 84: 597-608.

4 Ahearn DS, Sheibley RW, Dahlgren RA, Keller KE. Temporal dynamics of stream water chemistry in the last free-flowing river draining the western Sierra Nevada, California. J

$6 \quad$ Hydrol 2004; 295: 47-63.

Bobbink R, Hornung M, Roelofs JGM. The effects of airborne nitrogen pollutants on species diversity in natural and semi-natural European vegetation. J Ecol 1998; 86: 717-738.

Edwards AC, Cook Y, Smart R, Wade AJ. Concentrations of nitrogen and phosphorus in streams draining the mixed land-use Dee Catchment, north-east Scotland. J Appl Ecol 2000; 37 (Suppl. 1): 159-170.

12 Elser JJ, Marzolf ER, Goldman CR. Phosphorus and nitrogen limitation of phytoplankton growth in the freshwaters of North American: a review and critique of experiment enrichments. Can J Fish Aqua Sci 1990; 47: 1468-1477.

Fukushima T, Matsushige K. On the relationship between basin characteristics and river water quality in forest watersheds. J Jpn Soc Water Environ 1995; 18: 909-916 (In Japanese).

Interlandi S, Kilham SS. Assessing the effects of nitrogen deposition on mountain waters: a study of phytoplankton community dynamics. Water Sci Technol 1998; 38: 139-146.

20 Kavvadias VA, Alifragis D, Tsiontsis A, Brosfas G, Stamatelos G. Litterfall, litter accumulation and litter decomposition rates in four forest ecosystems in northern Greece. Forest Ecol Manag 2001; 144: 113-127.

Komai Y. Budgets and runoff characteristics of phosphorus in forested watershed. J Jpn Soc Water Environ 2004; 27: 591-594 (In Japanese). 
Kunimatsu T, Hamabata E, Sudo M, Hida Y. Comparison of nutrient budgets between three forested mountain watersheds on granite bedrock. Water Sci Technol 2001; 44: 129-140.

Lipson D, Näsholm T. The unexpected versatility of plants: organic nitrogen use and availability in terrestrial ecosystems. Oecologia. 2001; 128: 305-316.

Liu C, Westman CJ, Ilvesniemi H. Matter and nutrient dynamics of litter in pine (Pinus tabulaeformis) and oak (Quercus variabilis) plantations in the mountainous areas of North China, Silva Fennica 2001; 35: 3-13.

8 Liu C, Westman CJ, Berg B, Kutscu W, Wang GZ, Man R, Ilvesniemi H. Variation in litterfall-climate relationships between coniferous and broadleaf forests in Eurasia. Global Ecol Biogeogr 2004; 13: 105-114.

Motoshita M, Komatsu T, Moldrup P, de Jonge LW, Ozaki N, Fukushima T. Soil constituent facilitated transport of phosphorus from a high-P surface soil. Soil Found 2003; 43: 105114.

14 Newman MC, Dixon PM, Looney BB, Pinder JE. Estimating mean and variance for environment samples with below detection limit observations. Water Resour Bull 1989; 25: 905-916.

Ohte N, Mitchell MJ, Shibata H, Tokuchi N, Toda H, Iwatsubo G. Comparative evaluation on nitrogen-saturation of forest catchments in Japan and Northeastern United States. Water Air Soil Poll 2001; 130: 649-654.

Redfield GW. Quantifying atmospheric deposition of phosphorus: a conceptual model and literature review for environmental management. Technical Publication WRE No 360. South Florida Water Management District, West Palm Beach, F.L. 1998.

Richardson JS, Shaughnessy CR, Harrison PG. Litter breakdown and invertebrate association with three types of leaves in a temperate rainforest stream. Arch. Hydrobiol. 2004; 159: 309-325. 
Sakamoto M. Primary production by phytoplankton community in some Japanese lakes and its dependence on lake depth. Arch Hydrobiol 1966; 62: 1-28.

Shibata H. Proton budget analysis to understand forest stream chemistry: external budget and internal cycling. J Jpn Soc Water Environ 2004; 27: 579-583 (In Japanese).

Shibata H, Kuraji K, Toda H, Sasa K. Regional comparison of nitrogen export to Japanese forest streams. Scientific World 2001; 1(S2): 572-580.

Takeda I. The impact of coniferous forest under no management on diffuse pollutant loading (ш). Water Conservation Sci 2002; 46: 63-84 (in Japanese).

Toda H, Sasa K, Sato F, Shibata H, Nomura M, Ichikawa K, Fujito E, Takanishi T, Seiwa K, Tsukahara H, Iida T, Taniguchi N, Nakata M, Kuwabara S, Uchida T, Haruta Y, Inoue M, Yagi H, Tsukagoshi T, Kuraji K, Futada M, Ono H, Suzuki M, Imaizumi Y, Yamaguchi N, Takenaka C, Yurugi Y, Kawanabe S, Ando M, Nakanishi A, Nishimura K, Yamasaki M, Nagayama Y, Doi N, Katagiri S, Kofuji R, Shinmura Y, Inoue S, Ezaki T, Kohno S, Fujihisa M, Iwamatsu I, Imayasu K, Nakamura S, Tsukamoto J, Nogami K, Enoki T. Stream water chemistry of university forests over Japan. J Jpn Forest Soc 2000; 82: 308312 (in Japanese).

Tsukuda S, Sugiyama M, Harita Y, Nishimura K. Methodological re-examination of atmospheric phosphorus input estimates based on spatial microheterogeneity. Water Air Soil Pollut 2004; 152: 333-347.

Tsukuda S, Sugiyama M, Harita Y, Nishimura K. Atmospheric phosphorus deposition in Ashiu, central Japan — source apportionment for the estimation of true input to a terrestrial ecosystem. Biogeochemistry 2006; 77: 117-138.

Turner BL, Baxter R, Whitton BA. Nitrogen and phosphorus in soil solution and drainage streams in Upper Teesdale, northern England: implication of organic compounds for biological nutrient limitation. Sci Total Environ 2003; 316: 153-170. 
Umemoto S, Komai Y. Nutrient deposition from atmosphere. Annual Report of Hyogo Prefectural Institute of Public Health and Environmental Science http://www.iphes.pref.hyogo.jp/kikaku/seika/2003/seminar/umemoto.pdf 1-4. 2003.

4 Vitousek PM. Nutrient cycling and nutrient use efficiency. Am Nat 1982; 119: 553-572.

Vitousek PM, Howarth RW. Nitrogen limitation on land and in the sea: How can it occur? $6 \quad$ Biogeochemistry 1991; 13: 87-115.

Wakamatsu T, Konohira E, Shindo J, Yoshioka T, Okamoto K, Itaya A, Kim MS. Dissolved inorganic phosphate concentration in stream water in Japan and factors controlling the concentration. J Jpn Soc Water Environ 2006; 29: 679-686 (In Japanese).

10 Wardle DA, Walker LR, Bardgett RD. Ecosystem properties and forest decline in contrasting long-term chronosequences. Science 2004; 305: 509-513.

12 Webster JR, Benfield EF. Vascular Plant Breakdown in Freshwater Ecosystems. Annual Rev Ecol Syst 1986; 17: 567-594.

14 Whitton BA, Yelloly JM, Christmas M, Hernández I. Surface phosphatase activity of benthic algae in a stream with highly variable ambient phosphate concentrations. Verh Int Ver Limnol 1998; 26: 967-972.

Yoh M, Konohira E, Yagi K. Regional distribution of natural stream nitrate in central Japan. Water Air Soil Poll 2001; 130: 655-660.

Zhang Z. Doctoral Thesis on Export of Carbon, Nitrogen, and Phosphorus from Forested Watersheds in Japan. 2007; Chapter 2: 12-31.

Zhang Z, Fukushima T, Onda Y, Gomi T, Fukuyama T, Sidle R, Kosugi K, Matsushige K. Nutrient runoff from forested watersheds in central Japan during Typhoon storms: Implications for understanding runoff mechanisms during storm events. Hydrol Process 2007; 21: 1167-1178. 
Zhang Z, Fukushima T, Onda Y, Mizugaki S, Gomi T, Kosugi K, Hiramatsu S, Kitahara H, Kuraji K, Terajima T, Matsushige K. Characterization of diffuse pollutions from forested watersheds in Japan during storm events: its association with the features of rainfall and watershed. Sci Total Environ 2008; 390: 215-226.

6 
Table 1. Summary of information on the five study regions and the watersheds in the regions

\begin{tabular}{|c|c|c|c|c|c|c|c|c|c|}
\hline Region & Location & $\begin{array}{l}\text { Precipitat } \\
\text { ion }(\mathrm{mm} \\
\left.\mathrm{yr}^{-1}\right)\end{array}$ & $\begin{array}{l}\text { Mean } \\
\text { temp. } \\
\left({ }^{\circ} \mathrm{C}\right)\end{array}$ & $\begin{array}{l}\text { Species } \\
\text { structure }\end{array}$ & $\begin{array}{l}\text { Watershed } \\
\text { Code }^{\mathrm{a}}\end{array}$ & Watershed characteristic & M.E. $^{b}(m)$ & $\begin{array}{l}\text { Species } \\
\text { age }(\mathrm{yr})\end{array}$ & $\begin{array}{l}\text { Watershed } \\
\text { area (ha) }\end{array}$ \\
\hline \multirow[t]{4}{*}{ Aichi } & $136^{\circ} 57.9^{\prime} \mathrm{E}$ & \multirow[t]{4}{*}{2108} & \multirow[t]{4}{*}{15.4} & Cypress $^{\mathrm{c}}(48 \%)$ & A1 & Cypress forested & 166 & $23-38$ & 5.1 \\
\hline & \multirow[t]{3}{*}{$35^{\circ} 10.0^{\prime} \mathrm{N}$} & & & $\operatorname{Ceder}^{\mathrm{d}}(35 \%)$ & A2 & $\mathrm{DB}^{\mathrm{e}}$ forested & 170 & & 7.5 \\
\hline & & & & Others $(17 \%)$ & A3 & Cypress forested & 161 & $19-22$ & 3 \\
\hline & & & & & A4 & DB forested & 175 & & 3.5 \\
\hline \multirow[t]{6}{*}{ Kochi } & $133^{\circ} 07.7^{\prime} \mathrm{E}$ & 2782 & 14.6 & Cypress(56\%) & $\mathrm{K} 2$ & DB forested & 381 & $36-39$ & 45.3 \\
\hline & \multirow{5}{*}{$33^{\circ} 12.4^{\prime} \mathrm{N}$} & & & Ceder $(40 \%)$ & $\mathrm{K} 3$ & DB forested & 556 & $37-40$ & 4.9 \\
\hline & & & & Others $(4 \%)$ & K4 & Ceder forested & 481 & $37-40$ & 2.0 \\
\hline & & & & & K6 & Cypress forested & 381 & $36-39$ & 5.7 \\
\hline & & & & & K7 & Cypress forested & 368 & $35-39$ & 33.2 \\
\hline & & & & & K8 & Cypress forested & 275 & $37-39$ & 0.6 \\
\hline \multirow[t]{5}{*}{ Mie } & \multirow{5}{*}{$\begin{array}{l}136^{\circ} 23.4^{\prime} \mathrm{E} \\
34^{\circ} 26.9^{\prime} \mathrm{N}\end{array}$} & \multirow[t]{5}{*}{2560} & \multirow[t]{5}{*}{14.2} & Cypress(48\%) & M1 & Cypress forested & 180 & $30-33$ & 4.9 \\
\hline & & & & Ceder $(43 \%)$ & M2 & $\begin{array}{l}\text { Cypress forested, well managed, } \\
\text { cuttings for several time }\end{array}$ & 161 & $30-32$ & 1.2 \\
\hline & & & & Others $(9 \%)$ & M3 & Dense Cypress forested & 183 & $30-33$ & 3.5 \\
\hline & & & & & M5 & $\begin{array}{l}\text { Dense Cypress forested (no } \\
\text { understory species) }\end{array}$ & 181 & $30-33$ & 0.3 \\
\hline & & & & & M6 & Cypress forested & 192 & 31 & 0.2 \\
\hline
\end{tabular}




\begin{tabular}{|c|c|c|c|c|c|c|c|c|c|}
\hline & & & & & M7 & Cypress forested & 199 & $30-33$ & 3 \\
\hline \multirow[t]{4}{*}{ Nagano } & $138^{\circ} 22.5^{\prime} \mathrm{E}$ & 1487 & 10.8 & Cypress $(18 \%)$ & N1 & Cypress \& DB & 1133 & $35-42$ & 37 \\
\hline & $36^{\circ} 52.4^{\prime} \mathrm{N}$ & & & Ceder $(12 \%)$ & $\mathrm{N} 2$ & Cypress forested & 1153 & $35-40$ & 25 \\
\hline & & & & Others $(70 \%)$ & N5 & $\operatorname{Larch}^{\mathrm{f}}$ forested & 1186 & 54 & 0.6 \\
\hline & & & & & N6 & DB & 1270 & 45 & 1.8 \\
\hline \multirow[t]{7}{*}{ Tokyo } & $139^{\circ} 18.7^{\prime} \mathrm{E}$ & 1504 & 13.6 & Cypress $(25 \%)$ & $\mathrm{T} 1$ & Ceder \&DB & 698 & $15-35$ & 42.8 \\
\hline & $35^{\circ} 47.3^{\prime} \mathrm{N}$ & & & Ceder $(65 \%)$ & $\mathrm{T} 2$ & Ceder \&DB & 773 & $29-35$ & 12 \\
\hline & & & & Others $(10 \%)$ & $\mathrm{T} 3$ & Ceder forested & 760 & $33-35$ & 6.0 \\
\hline & & & & & & Ceder \& Cypress (man-made & & & \\
\hline & & & & & $\mathrm{T} 4$ & forests) & 750 & 16 & 0.6 \\
\hline & & & & & T5 & Ceder \& Cypress & 770 & $30-32$ & 1.3 \\
\hline & & & & & T6 & DB & 778 & & 1.6 \\
\hline
\end{tabular}

${ }^{a}$ the code showed in Fig. $1 ;{ }^{b}$ M.E. means the medium elevation; ${ }^{c}$ latin name: Chamaecyparis obtuse; ${ }^{\mathrm{d}}$ latin name: Cryptomeria japonica; ${ }^{\mathrm{e}} \mathrm{DB}$ :

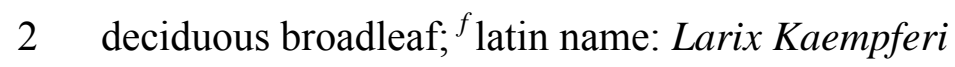


Table 2. Summary of nutrient concentrations $\left(\mu \mathrm{mol}^{-1}\right)$ and molar N:P ratio* 2

\begin{tabular}{|c|c|c|c|c|c|c|c|c|c|c|}
\hline & \multicolumn{6}{|c|}{$\mathbf{N}$} & \multicolumn{3}{|c|}{$\mathbf{P}$} & \multirow{2}{*}{$\begin{array}{l}\text { Ratio } \\
\mathrm{N}: \mathrm{P}\end{array}$} \\
\hline & DON & $\mathrm{NH}_{4}-\mathrm{N}$ & $\mathrm{NO}_{2}-\mathrm{N}$ & $\mathrm{NO}_{3}-\mathrm{N}$ & DIN & DTN & DOP & DIP & DTP & \\
\hline Min. & 0.18 & 0.07 & 0.07 & 0.48 & 0.60 & 0.75 & 0.02 & 0.02 & 0.03 & 7.04 \\
\hline Max. & 14.1 & 1.78 & 0.57 & 105 & 106 & 112 & 0.41 & 1.03 & 1.23 & 1858 \\
\hline Med. & 3.13 & 0.07 & 0.07 & 8.64 & 9.83 & 10.3 & 0.03 & 0.06 & 0.16 & 99.2 \\
\hline Ave. & 3.59 & 0.14 & 0.11 & 20.2 & 21.5 & 24.6 & 0.09 & 0.13 & 0.21 & 165 \\
\hline SD & 2.52 & 0.27 & 0.08 & 24.3 & 23.6 & 25.2 & 0.07 & 0.17 & 0.2 & 198 \\
\hline
\end{tabular}

*: Molar $\mathrm{N}: \mathrm{P} \approx 0.45 \mathrm{~N}: \mathrm{P}$ (by mass)

4

6

8

10

12

14

16

18 
Table 3. Means (standard deviations) of nutrient concentrations and N:P ratio at 26 sites

\begin{tabular}{|c|c|c|c|c|c|c|}
\hline Site & $\begin{array}{c}\text { Number of } \\
\text { samples }\end{array}$ & DON & $\mathrm{NO}_{3}-\mathrm{N}$ & DOP & DIP & $\mathrm{N}: P$ ratio \\
\hline $\mathrm{A} 1$ & 7 & $4.56(2.21)$ & $7.01(1.67)$ & $0.020(0.022)$ & $0.017(0.012)$ & $433(213)$ \\
\hline $\mathrm{A} 2$ & 7 & $4.63(2.18)$ & $3.06(1.00)$ & $0.039(0.031)$ & $0.018(0.013)$ & $176(75.9)$ \\
\hline A3 & 7 & $4.09(2.30)$ & $5.74(1.26)$ & $0.040(0.056)$ & $0.008(0.000)$ & 344 (185) \\
\hline A4 & 7 & $3.70(2.06)$ & $1.69(0.33)$ & $0.069(0.040)$ & $0.018(0.013)$ & $87.1(47.5)$ \\
\hline Aichi & 28 & $4.24(2.09)$ & $4.22(2.39)$ & $0.045(0.039)$ & $0.021(0.008)$ & $176(104)$ \\
\hline $\mathrm{K} 2$ & 10 & $2.34(1.68)$ & $10.2(5.53)$ & $0.079(0.080)$ & $0.118(0.094)$ & $88.8(69.4)$ \\
\hline $\mathrm{K} 3$ & 10 & $2.30(1.25)$ & $7.68(3.18)$ & $0.088(0.042)$ & $0.244(0.180)$ & $50.8(49.3)$ \\
\hline K4 & 9 & $1.98(1.51)$ & $1.45(1.05)$ & $0.125(0.095)$ & $0.282(0.091)$ & $8.05(2.37)$ \\
\hline K6 & 10 & $2.58(1.28)$ & $14.2(3.75)$ & $0.083(0.055)$ & $0.101(0.098)$ & $165(143)$ \\
\hline K7 & 10 & $2.79(1.02)$ & $15.8(5.81)$ & $0.086(0.062)$ & $0.064(0.085)$ & $147(61.3)$ \\
\hline K8 & 9 & $2.44(1.89)$ & $6.39(4.47)$ & $0.070(0.057)$ & $0.098(0.068)$ & $75.8(90.8)$ \\
\hline Kochi & 58 & $2.69(1.58)$ & $11.0(5.80)$ & $0.085(0.063)$ & $0.117(0.116)$ & $103(81.2)$ \\
\hline M1 & 11 & $2.79(1.32)$ & $11.3(8.11)$ & $0.082(0.080)$ & $0.031(0.023)$ & $248(285)$ \\
\hline M2 & 11 & $3.23(1.33)$ & $5.59(4.32)$ & $0.058(0.059)$ & $0.052(0.046)$ & $121(119)$ \\
\hline M3 & 11 & $3.34(1.83)$ & $10.0(8.03)$ & $0.090(0.064)$ & $0.061(0.061)$ & 109 (77.7) \\
\hline M5 & 9 & $2.51(1.26)$ & $12.4(5.06)$ & $0.113(0.091)$ & $0.109(0.095)$ & $71.6(23.2)$ \\
\hline M6 & 11 & $3.22(1.43)$ & $8.51(7.78)$ & $0.077(0.049)$ & $0.033(0.034)$ & 154 (179) \\
\hline M7 & 11 & $3.27(2.11)$ & $5.60(6.08)$ & $0.107(0.098)$ & $0.050(0.077)$ & $96.4(101)$ \\
\hline Mie & 64 & 3.12 (1.59) & $8.54(7.16)$ & $0.086(0.073)$ & $0.053(0.056)$ & $121(121)$ \\
\hline N1 & 8 & $3.82(2.73)$ & $55.8(12.1)$ & $0.108(0.069)$ & $0.088(0.085)$ & $356(156)$ \\
\hline $\mathrm{N} 2$ & 9 & $6.27(4.61)$ & $71.6(15.9)$ & $0.126(0.089)$ & $0.056(0.059)$ & $576(326)$ \\
\hline N5 & 8 & $3.81(3.96)$ & $24.0(11.5)$ & $0.135(0.081)$ & $0.332(0.139)$ & $65.7(47.1)$ \\
\hline N6 & 4 & $8.38(2.17)$ & $0.64(0.25)$ & $0.161(0.046)$ & $0.806(0.137)$ & $9.41(3.13)$ \\
\hline
\end{tabular}




\begin{tabular}{lllllll} 
Nagano & $\mathbf{2 9}$ & $\mathbf{4 . 9 4 ( 3 . 9 6 )}$ & $\mathbf{5 8 . 8 ( 2 4 . 3 )}$ & $\mathbf{0 . 1 2 7}(\mathbf{0 . 0 7 7})$ & $\mathbf{0 . 2 0 0 ( \mathbf { 0 . 2 2 1 } )}$ & $\mathbf{3 0 7}(\mathbf{2 8 2})$ \\
\hline $\mathrm{T} 1$ & 7 & $3.42(2.71)$ & $64.9(13.8)$ & $0.067(0.064)$ & $0.231(0.085)$ & $281(194)$ \\
$\mathrm{T} 2$ & 7 & $5.45(3.94)$ & $65.4(9.48)$ & $0.153(0.133)$ & $0.556(0.388)$ & $170(135)$ \\
$\mathrm{T} 3$ & 6 & $8.30(4.32)$ & $55.7(1.49)$ & $0.101(0.131)$ & $0.101(0.131)$ & $1106(503)$ \\
$\mathrm{T} 4$ & 6 & $4.50(4.78)$ & $74.9(8.45)$ & $0.121(0.048)$ & $0.508(0.138)$ & $134(52.7)$ \\
$\mathrm{T} 5$ & 6 & $4.45(4.30)$ & $63.8(16.2)$ & $0.079(0.085)$ & $0.432(0.336)$ & $190(103)$ \\
T6 & 4 & $4.03(4.47)$ & $63.1(5.11)$ & $0.157(0.124)$ & $0.427(0.255)$ & $134(55.1)$ \\
\hline Tokyo & $\mathbf{3 6}$ & $\mathbf{4 . 6 1 ( 3 . 7 9 )}$ & $\mathbf{6 6 . 2 ( 1 1 . 6 )}$ & $\mathbf{0 . 1 1 0 ( 0 . 0 2 4 )}$ & $\mathbf{0 . 3 8 9 ( \mathbf { 0 . 0 8 8 } )}$ & $\mathbf{2 5 6 ( 3 5 6 )}$ \\
\hline
\end{tabular}


Table 4. Pearson correlation coefficients and $P$ values between water quality items 2

\begin{tabular}{|c|c|c|c|c|c|c|c|}
\hline & DOC & DOP & DON & DIP & $\mathrm{NO}_{3}-\mathrm{N}$ & DTP & DTN \\
\hline$\overline{\mathrm{DOC}}$ & & 0.080 & $0.159^{*}$ & -0.071 & -0.022 & -0.033 & -0.005 \\
\hline DOP & & & $0.318^{* *}$ & $0.212^{* *}$ & $0.167^{*}$ & $0.532^{* *}$ & $0.193^{* *}$ \\
\hline DON & & & & 0.042 & $0.300^{* *}$ & $0.150^{*}$ & $0.391^{* *}$ \\
\hline DIP & & & & & $0.397^{* *}$ & $0.936^{* *}$ & $0.388^{* *}$ \\
\hline $\mathrm{NO}_{3}-\mathrm{N}$ & & & & & & $0.403^{* *}$ & $0.995^{* *}$ \\
\hline DTP & & & & & & & $0.404^{* *}$ \\
\hline DTN & & & & & & & \\
\hline
\end{tabular}

* Significant at the $P<0.05$ level; ** Significant at the $P<0.01$ level.

4

6

8

10

12

14 


\section{Figure Captions:}

2

Figure 1. Locations of studied regions and watersheds

4 Figure 2. Representative hydrographs on the sampling catchments (The double circle means the actual samples used in this study)

6 Figure 3. Vegetation type vs. water quality items and N:P ratio in five regions. The symbol on the top of column means significant difference at different level, with *** for $P$ $\leq 0.001, * *$ for $0.001<P \leq 0.01$, and $*$ for $0.01<P \leq 0.05$

Figure 4. Relationship between DTN and DTP in two types of forests in each region

10 Figure 5. Correlation between total phosphorous (TP) and total nitrogen (TN) deposition in Japan forests. The data are from Kunimatsu (2001) and Umemoto (2003) 
$2 \quad$ Fig. 1.

Legend

$5 \mathrm{~m}$ contour
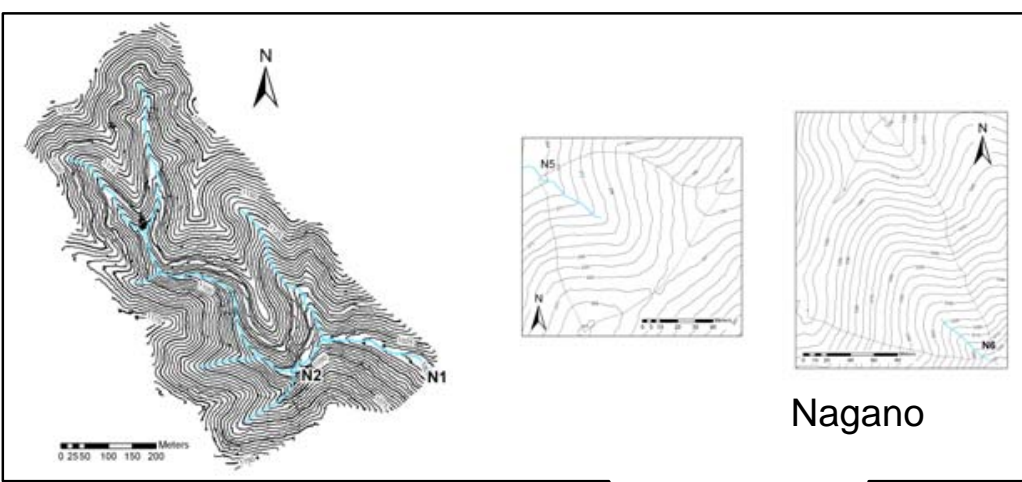

$25 \mathrm{~m}$ contour

Stream

Nagano
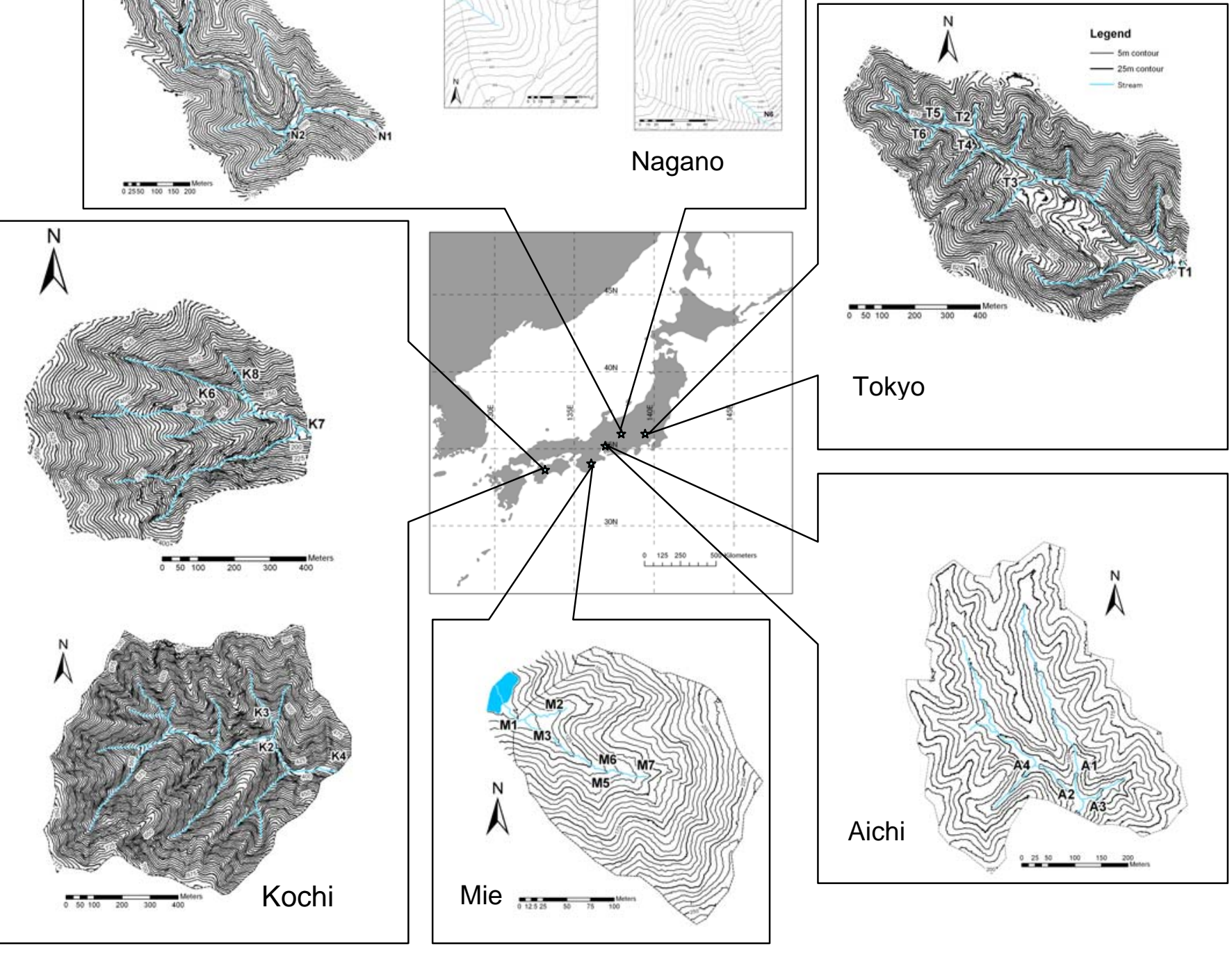
2 Fig.2.

4

6

8

10

12

14

16

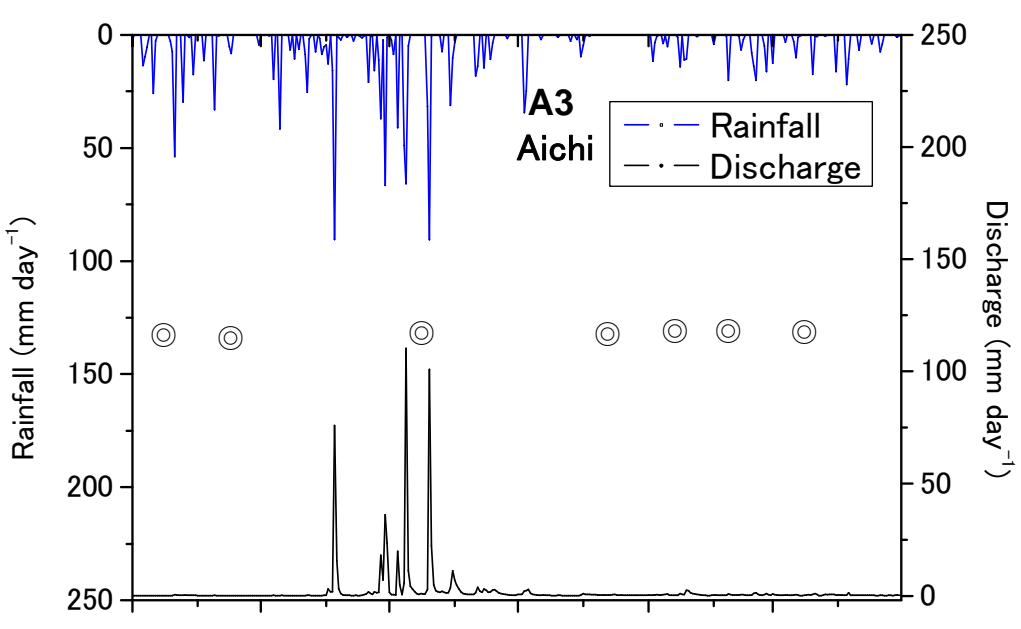

18

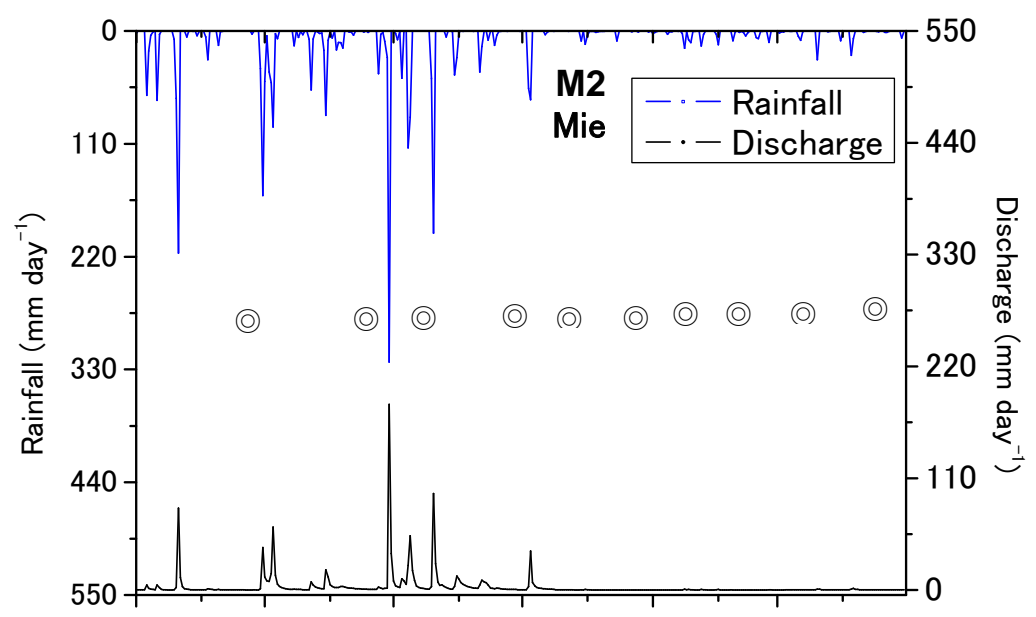

34

36

38 
$2 \quad$ Fig. 3.
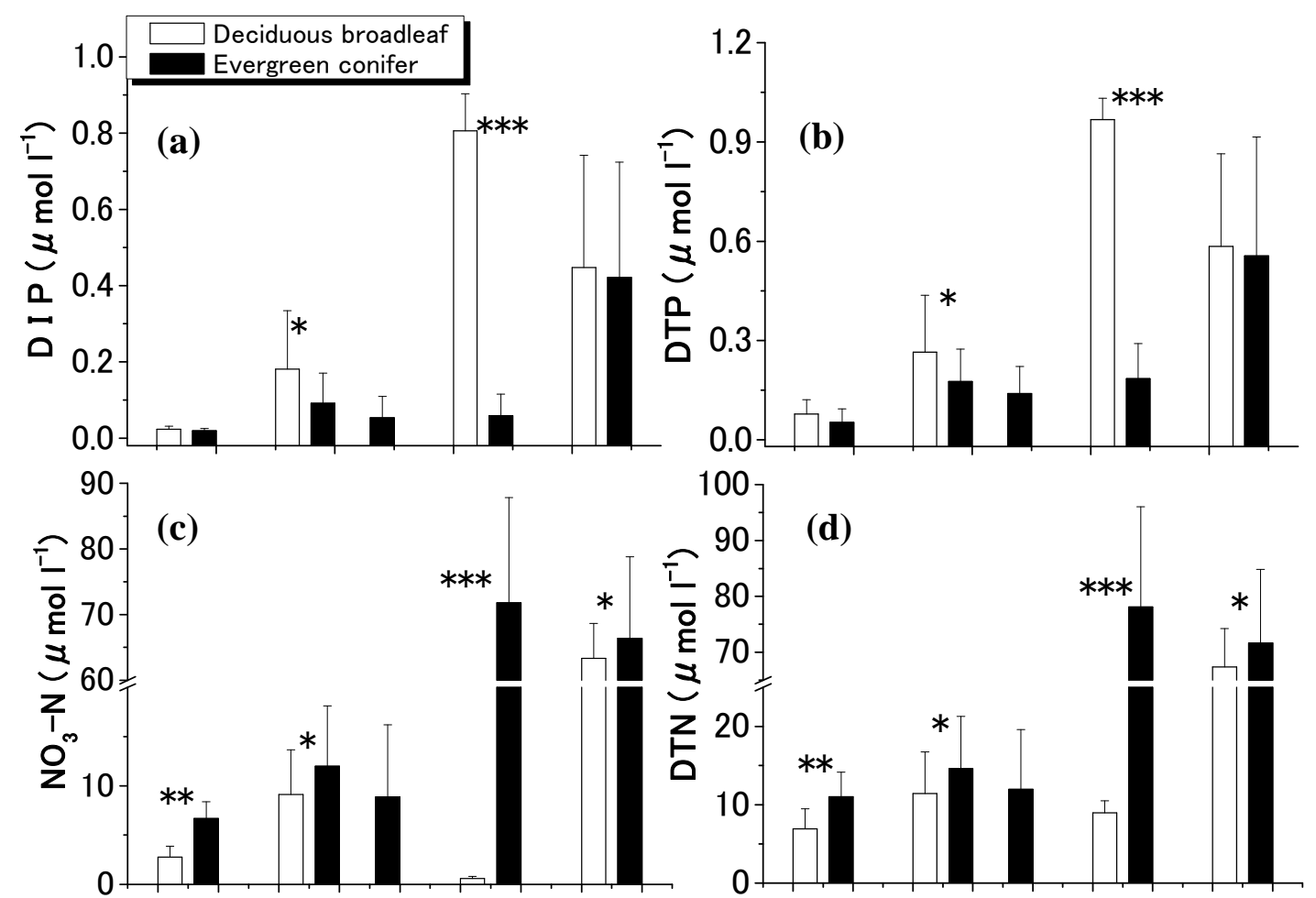

(d)
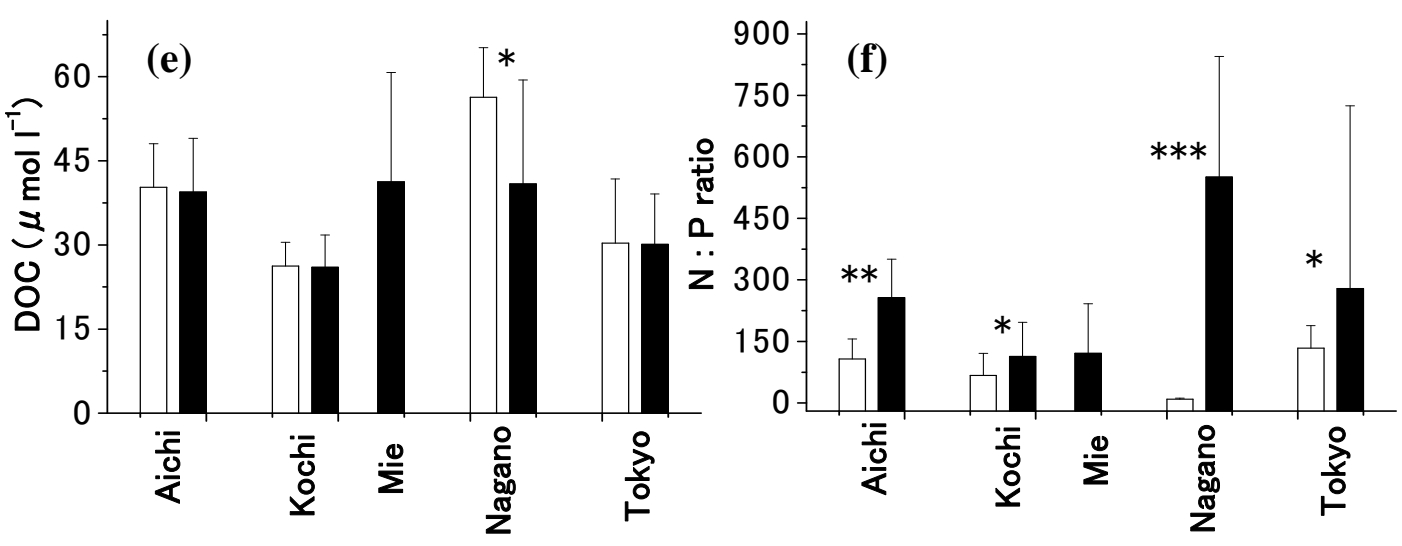
Fig. 4.
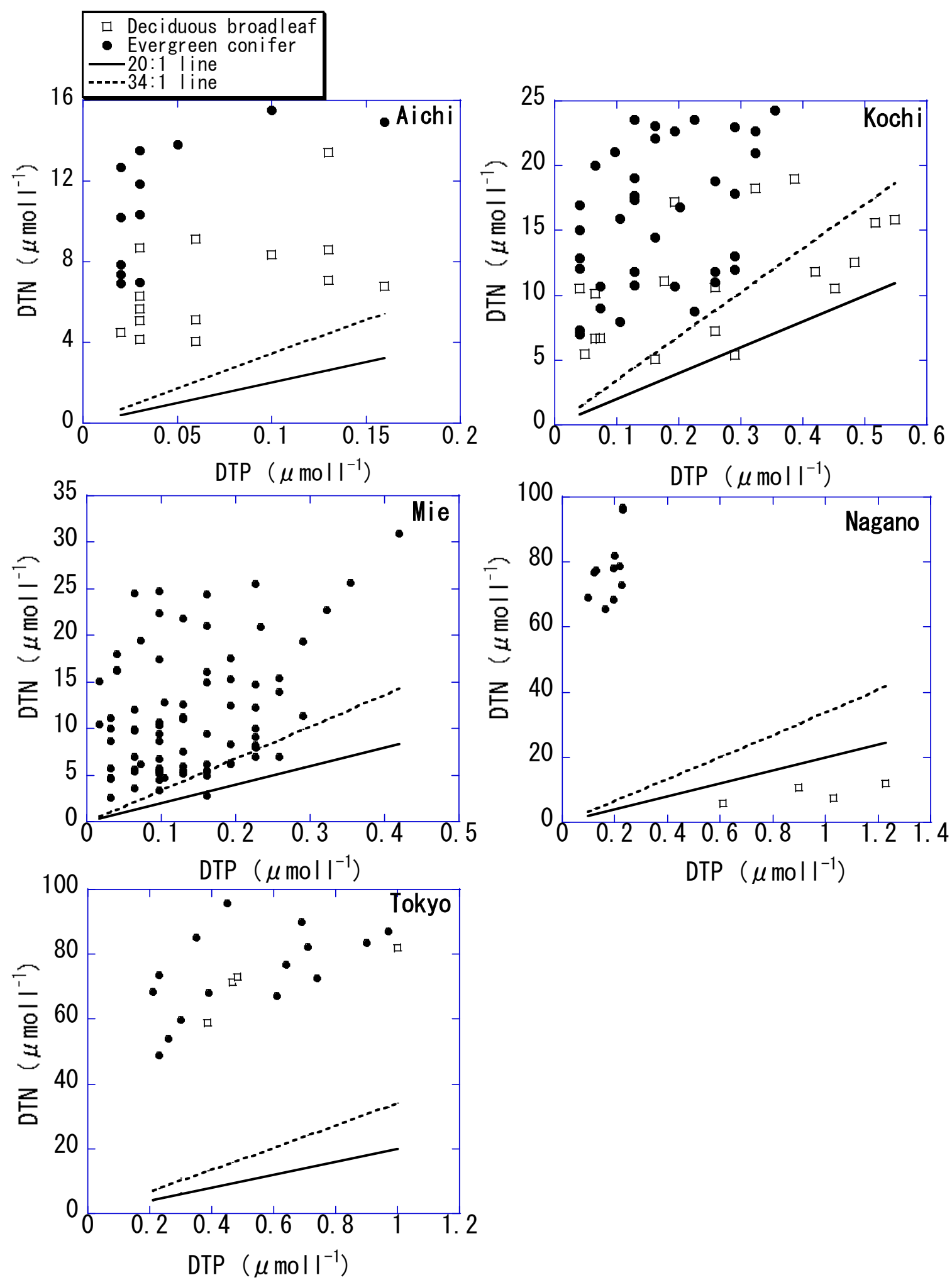

DTP $\left(\mu \mathrm{moll}^{-1}\right)$ 
2 Fig.5.

4

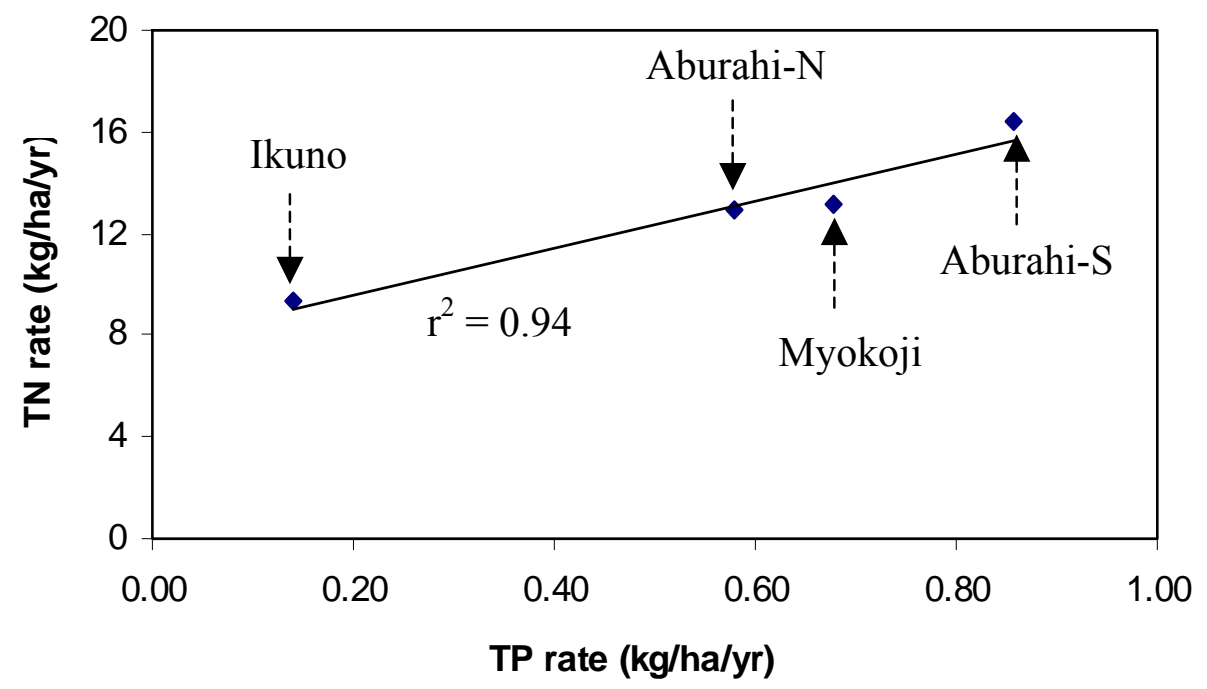

